\title{
喉頭乳頭腫の治療
}

$\begin{array}{ccccc}\text { 古田 茂 花田 } \begin{array}{c}\text { 武浩 } \\ \text { 大山 }\end{array} & \begin{array}{c}\text { 西薗 } \\ \text { 勝 }\end{array} & \text { 浩文 } & \text { 鮫島 } & \text { 篤史 }\end{array}$

\section{Treatment of Laryngeal Papilloma}

Shigeru Furuta, Takehiro Hanada, Hirofumi Nishizono, Atsushi Samejima, Masaru Ohyama

\begin{abstract}
There are many treatment for laryngeal papillomatosis, for example microlaryngeal surgery, endoscopic laser surgery using carbon dioxide or Nd : YAG laser and interferon therapy. Adult papillomatosis can be controlled well with surgery. The majority of cases of Juvenile laryngeal papillomatosis need frequent and repeated surgical resections.
\end{abstract}

\section{はじめに}

喉頭乳頭腫はウイルスとの関連で注目を集めている 良性腫瘍である。また, 腫瘍の初発年齢, 発生部位, 増殖態度さらには感染経路などの面から臨床疫学的, 分子生物学的に多くの関心と興味が持たれている疾患 である。

喉頭乳頭腫は初発時期の違いから若年型と成人型に 分類される. 前者では生後 6 力月から $4 \sim 5$ 歳の間に 発症し, 多発性, 再発性の臨床経過をとる。しかし, 思春期以後にしばしば消退し，表 1 のように，human papilloma virus (HPV) の関与が明らかである ${ }^{1,2)}$. 後 者は, HPV の関与は低く, 単発性である. 腫場は角化 傾向が強く，時に癌化することがある ${ }^{3)}$.

\section{喉頭乳頭腫の治療}

喉頭乳頭腫の治療の基本は，顕微鏡下の外科的切除 である. 単発性, 角化傾向の強い例では, 単純な切除 のみで治癒可能である，成人型乳頭腫が当てはまる。 しかし, 腫瘍の初発部位と占拠部位によっては切除や 摘出方法が異なる。一方, 若年型乳頭腫は未だ治療法 は確立していないため, 多くの治療法は検討されてい
る. 小児が対象であるので, 疾病の制御と喉頭機能の 正常化という困難な問題に対処しなければならない. また, 再発が多いことも治療期間の遷延化に繫がって いる. Antarasena ${ }^{4}$ は小肾喉頭乳頭腫 170 症例に対し て, 全例喉頭微細手術を行い, 声門下部への進展例で は気管支鏡を併用して切除を行っている，再発性があ るため, 頻回の手術を要している.

最近では切除にあたり，顕微鏡下喉頭微細手術が主 体で，レーザー光線を併用することが一般的であ $3^{5,6)}$. 多発性の場合や前交連に腫瘍が存在する場合に は, 腫瘍の全切除は困難なことが多い.その際には, 音声機能の保持や術後の瘢痕形成の防止のため, 部分 切除にとどめることもある。癌化を認める症例では, その治療法は喉頭癌の治療に準じて行われている3 (表 2 ).

\section{外科的切除の注意点}

喉頭乳頭腫の外科的切除にあたり，大山は顕微鏡下 喉頭微細手術施行時の注意点として次の 5 項目をあげ ている5 .

1. 気管内㨉管の操作は腫瘍を傷つけないように十 分慎重に行う。

鹿児島大学医学部耳鼻咽喉科学教室：干 890 鹿児島市桜ヶ丘 $8-35-1$

Department of Otolaryngology, Faculty of Medicine, Kagoshima University : 8-35-1, Sakuragaoka, Kagoshima-shi,

Kagoshima 890

原稿受理：1995 年 12 月 1 日 
表 1 human papilloma virus のタイプ別疾患分類(文献 2 , より引用)

\begin{tabular}{|c|c|c|}
\hline 型 & 臨床像 & 悪性化 \\
\hline 1 & Myrmercia 疮贅 & 良性 \\
\hline 2 & 尋常性疣贅, ときに尖圭コンジローマ & 良性 \\
\hline $3,10,28$ & 青年性扁平疣贅 & 悪性化はまれ \\
\hline 4 & 足底疗贅，尋常性疗贅 & 良性 \\
\hline 6,11 & 尖圭コンジローマ, 喉頭乳頭腫 & 通常良性 \\
\hline 7 & 尋常性疣贅 & 良性 \\
\hline $\begin{array}{l}5,8,9,12,14,15 \\
17,19-25,36,40\end{array}$ & EV 患者の青年性扁平疣贅, 皮膚癌 & 一部で悪性化あり \\
\hline 13,32 & oral focal epithelial hyperplasia & 悪性化あり \\
\hline $\begin{array}{c}16,18,31,33,35 \\
39\end{array}$ & $\begin{array}{l}\text { 子宮癌, Bowen 病, Bowenoid papulosis } \\
\text { 喉頭癌, 食道癌, 気管支癌 }\end{array}$ & 高度に悪性化 \\
\hline 26 & 免疫異常者における皮膚病贅 & 不明 \\
\hline 27 & 腎移植者における皮膚疗贅 & 不明 \\
\hline 29 & 皮虞疮贅 & 不明 \\
\hline 30,40 & 喉頭癌 & 癌 \\
\hline 34 & Bowen 病 & 表皮内癌 \\
\hline 37 & ケラトアカントーマ & 良性皮膚腫瘍 \\
\hline 38 & メラノーマ & 悪性 \\
\hline 41 & コンジローマ, 扁平疮贅 & 良性 \\
\hline 42 & 外陰部疣贅 & 良性 \\
\hline 45 & コンジローマ, 子宮癌 & 悪性化あり \\
\hline 51 & コンジローマ & 良性 \\
\hline 52 & 子宮頸癌 & 悪性化あり \\
\hline
\end{tabular}

表 2 喉頭乳頭腫の治療

外科的切除
腫瘍切除
レーザー切除
$\quad\left(\mathrm{CO}_{2}\right.$ レーザー, $\mathrm{Nd}: \mathrm{YAG}$ レーザー)
喉頭部分切除
喉頭全摘出術
その他の治療法
エストラジオール
ワクチン
インターフェロン
$\mathrm{BLM,PEP}$
イソプリノジン

2. 必要ならば，気管切開後，同部より挿管チュー ブを挿入して麻酔をする。

3 。喉頭直達鏡の挿入, 展開, 固定時の各操作は熟 練者が慎重に行う。

4. 手術は顕微鏡下に行い, 必要最小限の侵襲に止 める.

5. 健常粘膜を損傷した場合は，同創部に対してフ
ィブリン糊を塗布するか, 低出カレーザー照射をして おく.

音声外科的に考えると，健常粘膜への損傷を防ぐこ とが第一条件である。しかし, 一方では, 腫瘍の再発 率も高いので十分に切除することも必要である.

\section{レーザー治療と音声機能}

$\mathrm{HPV}$ が皮膚や粘膜上皮で発育する場合は，ウイル ス DNA 合成は顆粒細胞層で最も活発に生じる.また, viral capsid antigen は角化層に分布するため, HPV 由来の乳頭腫は角化層に限局していると考えられる. したがって，理論的には，乳頭腫の切除は上皮層のみ の蒸散で十分とされている7).

レーザー外科の使用レーザー光は炭酸ガスレーザ 一, Nd：YAG レーザーが一般的である。顕微鏡観察 の視野内の腫場を蒸散させるには, 炭酸ガスレーザー が有用である ${ }^{8)}$. 腫瘍の大きさと範囲によって, 出力を 調節しながら効果的に蒸散しうる。レーザー光による 周辺組織の損傷や扦管チューブの損傷の防止のため, 生食水を浸したガーゼを挿入することで対処する。そ のためには, 顕微鏡下にレーザー切除を行うことが必 
表 3 鹿児島大学で最近 10 年間に経験した喉頭乳頭腫症例

\begin{tabular}{|c|c|c|c|c|c|c|}
\hline 症例 & 年齢 & 性 & $\begin{array}{c}\text { 喉頭微細手術 } \\
\text { の回数 }\end{array}$ & レーザーの使用 & 他の治療法 & 予後 \\
\hline 1 & 70 & $\mathrm{~F}$ & 1 & \multirow{5}{*}{$\begin{array}{c}\mathrm{Nd}: \mathrm{YAG}, \mathrm{CO}_{2} \\
\mathrm{CO}_{2}\end{array}$} & 喉頭全摘出術 & 軽快 \\
\hline 2 & 59 & $\mathrm{~F}$ & 3 & & & 治癒 \\
\hline 3 & 54 & M & 3 & & PEP 局注 & 治癒 \\
\hline 4 & 46 & M & 1 & & & 治癒 \\
\hline 5 & 21 & M & 1 & & & 治癒 \\
\hline
\end{tabular}

要とされる．また，酒向らは帛，2段階手術を行うこと を推奨している.レーザー切除は効果を高めるために, 過度の組織蒸散を伴うことがある.第 1 段階では, 腫 瘍切除に止め, 過度の組織蒸散を防ぐ。第 2 段階では, 腫瘍が縮小しているので, 病巣の十分な確認をするこ とが可能となり, 術後の web 形成の防止に役立つと考 えられる。

$\mathrm{Nd}$ : YAG レーザーは内視鏡とともに使用可能で ある利点があり, その主な作用は蒸散ではなく, 組織 凝固と止血作用である．炭酸ガスレーザー照射では死 角になる非直線的な部位のレーザー治療に威力を発揮 する，さらに，喉頭あるいは気管支ファイバー下に用 いれば，喉頭から気管に及ぶ広範囲の腫場の切除に適 している.また, われわれが開発した接触型プローブ を用いれば，顕微鏡下にも安全に鉗子やメスの代用と して用いることが可能である5

\section{その他の治療法}

若年型喉頭乳頭腫では, 多発性, 再発性の特徵があ り, 腫湯の制御に難渋していたため, これまで種々の 治療法が検討されてきた。 その多くは外科的切除に他 の治療法を併用するものである.他の治療法としては, エストラジオールの局注 ${ }^{10)}$, ワクチン ${ }^{11}$, インターフェ ロン ${ }^{12,13)}$, ブレオマイシンの局注, イソプリノジン ${ }^{14)}$ どが用いられている。しかし, いずれも確固たる治療 成績を上げていないのが現状であろう。

その中にあって, 1981 年 Haglund らが, 小児喉頭乳 頭腫にインターフェロンが有効であった症例を報告し て以来, 喉頭乳頭腫にインターフェロンが有効である との報告が多くなされている ${ }^{12,13)}$.しかし, 本邦では, インターフェロンは保険の適応がなく患者の経済的負 担を強いることになる.

\section{治療成績と予後}

成人型喉頭乳頭腫では, 一部の癌化する症例を除い て比較的予後は良好である.われわれの経験でも最高
3 回の切除で再発を認めていない. 1 回の切除のみに て軽快する症例もみられる（表 3 )。

一方, 若年型喉頭乳頭腫は, 再発を繰り返すことが 多い. しかし, 思春期以後には自然消退する症例も多 くみられるのも事実である。乳児期において気管切開 を余儀なくされた症例では, 小児期における音声機能 獲得の機会を逸することになる。 また, 頻回の手術に よって, web 形成や喉頭内の瘢痕形成によって, 新た な音声外科の対象となる場合も多い. 若年性喉頭乳頭 腫には, 確固たる治療法が確立されていないので, そ の治療法の開発が今後のわれわれの課題と考えられ る.

\section{文献}

1) 大山 勝, Antrasena, S.,吉田浩己, 他：タイ国に おける若年性喉頭乳頭腫の臨庄疫学的ならびにウ イルス学的研究。喉頭, $1: 46-51,1989$.

2) 大山 勝, 藤吉利信, 牛飼雅人 : 喉頭乳頭腫. 喉 頭疾患 (耳鼻科 MOOK), pp.191-204, 1993.

3）宮下 弘, 鈴木一元, 峯田周幸, 他：癌化した喉 頭乳頭腫の一例. 日気食会報, 41：304-309, 1990.

4) Antarasena, S. : Clinical study of juvenile laryngeal papilloma. Acta Otolaryngol (Stockh) suppl, 458 : 163-166, 1988.

5）大山 勝, 古田 茂, 河野もと子 : 喉頭パピロー マ. JOHNS, $8: 475-479,1992$.

6) 田中康政, 田中信三, 平野 実: 喉頭乳頭腫の臨 床統計.耳鼻臨床, 補 $62 ： 47-55,1993$.

7) Kashima, H.K., Shak, K. : Recurrent respiratory papillomatosis. clinical overview and management principles. Obst Gynecol Clincs North Amer, 14 : 581-588, 1987.

8) Strong, M.S., Vaughan, C.W., Healy, G.B., et al. : Recurrent respiratory papillomatosis. Ann. Otol., $85:$ 508-517, 1976.

9）酒向 司，他：喉頭乳頭腫に対する喉頭顕微鏡下 
レーザー術一 2 段階手術の試み一喉頭， $3 ： 38$ 41, 1991.

10) Szpunar, J. : Laryngeal papillomatosis. Acta Otolaryngol, 63 :74-86, 1967.

11) Gross, C.W. : Current management of juvenile laryngeal papillomata. laryngoscope, $80: 532-$ 543, 1970.

12) Haglund, S., Lundquist, P.G., Cantell, K., et al. : Interferon therapy Juvenile laryngeal papillomatosis. Arch Otolaryngol, 107 : 327-332, 1981.

13）赤荻勝一, 浅井正嗣, 今村純一, 他：成人喉頭乳
頭腫に対する $\mathrm{CO}_{2}$ レーザーとインターフェロン 併用療法治療経験。耳鼻臨床, 補 $36: 217-222$, 1989.

14) Elo, J., Mate, Z. : Combined therapy with isoprinosine and $\mathrm{CO}_{2}$ laser microsurgery for the treatment of laryngeal papillomatosis. Arch Otolaryngol, $244: 342-345,1988$.

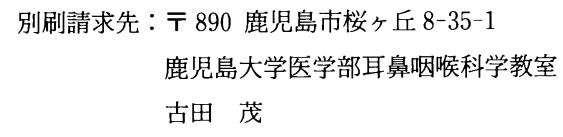

